\title{
GDNF, A Neuron-Derived Factor Upregulated in Glial Cells during Disease
}

\author{
Marcelo Duarte Azevedo, Sibilla Sander and Liliane Tenenbaum * \\ Laboratory of Molecular Neurotherapies and NeuroModulation, Center for Neuroscience Research, Lausanne \\ University Hospital, CHUV-Pavillon 3, av de Beaumont, CH-1010 Lausanne, Switzerland; \\ Marcelo.Duarte-Azevedo@chuv.ch (M.D.A.); sibilla.sander@chuv.ch (S.S.) \\ * Correspondence: Liliane.Tenenbaum@chuv.ch
}

Received: 3 December 2019; Accepted: 3 February 2020; Published: 7 February 2020

\begin{abstract}
In a healthy adult brain, glial cell line-derived neurotrophic factor (GDNF) is exclusively expressed by neurons, and, in some instances, it has also been shown to derive from a single neuronal subpopulation. Secreted GDNF acts in a paracrine fashion by forming a complex with the GDNF family receptor $\alpha 1$ (GFR $\alpha 1$ ), which is mainly expressed by neurons and can act in cis as a membrane-bound factor or in trans as a soluble factor. The GDNF/GFR $\alpha 1$ complex signals through interactions with the "rearranged during transfection" (RET) receptor or via the neural cell adhesion molecule (NCAM) with a lower affinity. GDNF can also signal independently from GFR $\alpha 1$ by interacting with syndecan-3. RET, which is expressed by neurons involved in several pathways (nigro-striatal dopaminergic neurons, motor neurons, enteric neurons, sensory neurons, etc.), could be the main determinant of the specificity of GDNF's pro-survival effect. In an injured brain, de novo expression of GDNF occurs in glial cells. Neuroinflammation has been reported to induce GDNF expression in activated astrocytes and microglia, infiltrating macrophages, nestin-positive reactive astrocytes, and neuron/glia (NG2) positive microglia-like cells. This disease-related GDNF overexpression can be either beneficial or detrimental depending on the localization in the brain and the level and duration of glial cell activation. Some reports also describe the upregulation of RET and GFR $\alpha 1$ in glial cells, suggesting that GDNF could modulate neuroinflammation.
\end{abstract}

Keywords: glial-cell-line-derived neurotrophic factor; microglia; astrocyte; neuroinflammation; rearranged during transfection; GDNF family receptor alpha 1; gene therapy; Parkinson's disease

\section{Introduction}

Glial cell line-derived neurotrophic factor (GDNF) has been isolated from the conditioned media of a rat glioma cell line on the basis of its trophic activity towards primary cultures of dopaminergic neurons [1].

Following the administration of GDNF family ligands (GFL) in animals, neurorestorative effects have been demonstrated in models of several neurological diseases [2-4]. However, in cases of high doses and long-term administration, aberrant sprouting and negative feedback effects on neurotransmitter homeostasis have been observed [5-8].

Two members of the GFL, GDNF and neurturin, have been evaluated in clinical trials for the treatment of Parkinson's disease (PD) $[9,10]$. Although positron-emission tomography (PET) scan imaging has evidenced clear functional improvements [11,12], and post-mortem analysis has demonstrated neuronal sprouting at the site of delivery [13], clinical outcomes have been disappointing. Therefore, better knowledge of GDNF's mechanism of action in vivo in complex neuronal circuits is urgently needed in order to revisit the relevant clinical paradigms. 
GDNF is mainly expressed during development and is involved in neuronal specification [14-17]. In a healthy adult brain, GDNF expression decreases and is restricted to specific regions: the cortex, hippocampus, striatum, substantia nigra (GDNF mRNA expression in substantia nigra dopaminergic neurons has been observed in [18] but not in [19]. This discrepancy could be explained by the differences between the probes used for in situ hybridization, the sensitivity of the method (digoxygenin-labeled versus radiolabeled probes), and the sex of the animals (female versus male)), thalamus, cerebellum, and spinal cord [20-22]. GDNF is a secreted factor [23] that is primarily expressed by neurons and acts mainly on neurons expressing the "rearranged during transfection" (RET) receptor. In a few instances, it has also been demonstrated to derive from a specific neuronal subpopulation $[18,20]$. For example, in the striatum, only interneurons [24] (mainly parvalbumin-expressing interneurons) $[18,19]$ express GDNF. Interestingly, the role of parvalbumin neuron-derived GDNF in the maintenance of dopaminergic neurons in the adult brain has been demonstrated using conditional knock-out mice [25]. Thus, in a healthy rodent brain, GDNF appears to be a neuron-derived neurotrophic factor rather than a glia-derived neurotrophic factor. The pattern of GDNF expression is different in a diseased brain. Indeed, de novo GDNF expression in glial cells has been described in numerous models of diseases, usually concomitantly with neuroinflammation.

In this review, we will discuss the dual role of GDNF upregulation in glial cells during neurodegeneration and repair. Other reviews covering the expression of neurotrophic factors by glial cells already exist $[26,27]$. Contradictory conclusions often arise from data obtained in vivo and in vitro (see discussion in reference [28]). In the present review, for clarity, we will focus on the expression of GDNF and its receptors in the nervous system in vivo, except for some aspects that have only been addressed in vitro.

\section{Glial Cells Express GDNF during Disease}

GDNF is expressed by neurons in developing [29,30] and adult nervous systems $[18,20,22,29,30]$. The expression patterns of GDNF have been confirmed using genetically modified mice [31] and do not match the astrocyte distribution, as revealed using anti-glial fibrillary acid protein (GFAP) antibodies [20]. Therefore, the name given to this neurotrophic factor can be misleading. Contrasting most publications that have failed to demonstrate GDNF glial expression in a healthy brain, Ubhi et al. have shown that a small proportion (around 6\%) of GDNF-expressing cells are glial [32].

Numerous studies have evidenced the de novo expression of GDNF by glial cells in an injured brain (see Table 1). In disease models, neuroinflammation can upregulate GDNF expression in activated astrocytes [33-40], microglia and infiltrating macrophages [33,36,41-45], nestin/GFAP-positive reactive astrocytes [46], and ionized calcium-binding adapter molecule 1 (Iba1)-positive neuron-glial antigen 2 (NG2) expressing macrophage/microglia-like cells [47]. This disease-related GDNF overexpression can be either beneficial $[47,48]$ or detrimental depending on the age of the animal [49], the length of the neuroinflammatory response [36,50], and the type of glial cells activated [28].

GDNF produced by activated microglia/macrophages can lead to a repair of central nervous system (CNS) injuries. After striatal mechanical injury [41,42] and spinal cord injury [43], activated microglia and macrophages express GDNF, thereby inducing axonal sprouting and locomotor improvements. Indeed, in the latter model [51], inhibition of GDNF expression using antisense oligonucleotides drastically reduced axonal sprouting [51]. In the 6-hydroxydopamine (6-OHDA) PD model, around $60 \%$ of surviving tyrosine hydroxylase $(\mathrm{TH})$-positive neurons were located near NG2 cells that expressed GDNF [47]. In the 1-methyl-4-phenyl-1,2,3,6-tetrahydropyridine (MPTP) PD model, cinnamon-induced neuroprotection was shown to be mediated by astrocytic GDNF overexpression in the substantia nigra. The role of astrocyte-derived GDNF in this model was demonstrated by the absence of neuroprotection in knock-out mice lacking GDNF expression in astrocytes [39]. 
Table 1. Non-neuronal glial cell line-derived neurotrophic factor (GDNF) expression during disease.

\begin{tabular}{|c|c|c|c|}
\hline Cell Type & Disease Model & Methods Used & References \\
\hline \multirow{3}{*}{ Macrophages/Microglia } & Striatal mechanical injury & ISH + immunohistochemistry & {$[41,42,44]$} \\
\hline & Experimental autoimmune neuritis & Double immunofluorescence & [45] \\
\hline & LPS-induced inflammation & Double immunofluorescence & {$[36,43]$} \\
\hline \multirow{6}{*}{ Astrocytes } & Quinolic acid lesion & Double immunofluorescence & {$[34,35]$} \\
\hline & LPS-induced inflammation & Double immunofluorescence & [36] \\
\hline & \multirow{2}{*}{ 6-OHDA } & ISH + immunofluorescence & [37] \\
\hline & & Double immunofluorescence & [38] \\
\hline & MPTP & Double immunofluorescence & [39] \\
\hline & Spinal cord ischemia & Double immunofluorescence & [40] \\
\hline Nestin-Expressing Reactive Astrocytes & MPTP & Double immunofluorescence & {$[46]$} \\
\hline Microglia-Like NG2-Expressing Cells & 6-OHDA & Double immunofluorescence & {$[47]$} \\
\hline
\end{tabular}

ISH, in situ hybridization; 6-OHDA, 6-hydroxydopamine; LPS, lipopolysaccharide: MPTP; 1-methyl-4-phenyl-1,2,3,6-tetrahydropyridine; neuron-glial antigen 2 (NG2). 
In addition, macrophage-mediated GDNF delivery based on transduced hematopoietic stem cell (HSC) transplantation has successfully rescued nigral dopaminergic neurons and improved motor function in a PD mouse model $[52,53]$. Chen et al. showed that these gene-modified macrophages/ microglia expressing GDNF are recruited to the areas affected by dopaminergic neuron loss and are present in the immediate surroundings of tyrosine hydroxylase $(\mathrm{TH})$ positive cells.

However, glial GDNF overexpression could be a double-edged sword. Indeed, after a mechanical injury of the striatum, GDNF-induced axonal sprouting failed to cross over the wound edge [41]. This dual effect of local GDNF overexpression was also observed in a spinal cord repair paradigm in which a transplanted nerve root genetically modified with a lentiviral vector expressing GDNF in Schwann cells stimulated the regeneration of motor neuron axons locally but not beyond the lesion [6]. It should be noted, however, that the deleterious effect of local GDNF overexpression was not limited to the glia, since long-lasting GDNF overexpression by neurons can also lead to aberrant sprouting in the case of ectopic localization $[5,54]$.

Transgenic mice expressing GDNF, either from an endogenous locus or from a GFAP promoter, revealed that astrocytic-derived GDNF overexpression is responsible for TH downregulation, decreased dopaminergic neurotransmission, and motor deficits [28].

\section{Glial Cells Express GDNF Receptors during Disease}

GDNF forms a complex with its primary receptor, GFR $\alpha 1$, which can be membrane-bound or released in a soluble form $[55,56]$. The existence of a soluble form of GFR 1 has been shown in the primary cultures of neurons. The GDNF-GFR $\alpha 1$ complex then binds the RET [22,57] present on neuronal cell bodies and terminals of several different pathways, such as nigro-striatal dopaminergic neurons [58,59], spinal motor neurons [60], noradrenergic neurons of the locus coeruleus [61], enteric neurons [62], and sensory neurons [63]. The GDNF-GFR $\alpha 1$ complex can also bind to and induce signaling through the neural adhesion molecule, NCAM [64-67]. GDNF can furthermore directly interact with the heparin sulfate proteoglycan, syndecan-3 [68-70]. Interestingly, GDNF binding to heparan sulfate has been shown to be beneficial for the protection of dopaminergic neurons in the 6-OHDA rat model of PD [71].

The upregulation of GFR $\alpha 1$ and RET has been reported in glial cells under pathological conditions $[34,35,72-74]$ (see Table 2).

RET was shown to be expressed in microglia in the brain tissue of patients with PD but not in healthy controls [72]. RET and its phosphorylated form (pRET) were also gradually increased in the microglia during disease progression in a transgenic mouse model of amyotrophic lateral sclerosis (ALS) $[74,75]$. In parallel, RET expression was decreased in motor neurons. These data suggest that motor neurons die due to a lack of response to neurotrophic factors or due to an excess of neurotoxic compounds derived from activated microglia.

On the other hand, increased neuronal survival concomitant with RET activation in the microglia was described in hippocampal slices treated with the excitotoxin, N-methyl-D-aspartate (NMDA) [73].

Excitatory amino acids induced GDNF and GFR $\alpha 1$ but not RET de novo expression via astrocytes in the striatum following treatment with quinolinate or kainate [34,35]. Similarly, after a mechanical lesion of the spinal cord in adult rats, GDNF and GFR $\alpha 1$ were upregulated in the astrocytes [76]. 
Table 2. Upregulation of the glial cell line-derived neurotrophic factor (GDNF) receptors in activated glial cells.

\begin{tabular}{|c|c|c|c|c|}
\hline Receptor & Cell Type & Disease/Lesion & Methods & Reference \\
\hline \multirow{3}{*}{ GFR $\alpha 1$} & \multirow{3}{*}{ Astrocytes } & Rat striatum treated with quinolinic acid & Double immunofluorescence & [35] \\
\hline & & Rat striatum treated with quinolinic acid or kainic acid & GFR $\alpha 1$ immunoreactivity, morphology & {$[34]$} \\
\hline & & Spinal cord mechanical injury & $\begin{array}{c}\text { GFR } \alpha 1 \text { immunoreactivity, localization in white matter, } \\
\text { morphology. }\end{array}$ & [76] \\
\hline RET & Microglia & Human PD and aging & Single immunohistochemistry, morphology & [72] \\
\hline RET, pRET & Microglia & ALS transgenic mice & Double immunofluorescence. & [74] \\
\hline pRET & Microglia? & Rat hippocampal slices treated with NMDA and exogenous GDNF & Immunofluorescence combined with isolectin IB4 * & [73] \\
\hline
\end{tabular}




\section{Conclusions and Further Prospects}

The physiological role of GDNF has been subject to debate. In fact, embryonic Gdnf knock-out mice result in neonatal death due to renal agenesis $[79,80]$. To better understand the importance of GDNF for the survival of catecholaminergic neurons in vivo, in the adult brain, conditional knock-out of $G d n f$ has been carried out, resulting in controversial conclusions. In one study, GDNF has been highlighted as an essential factor for the survival of these neurons [81]. Furthermore, a recent article has shown that GDNF is necessary for the maintenance of mesencephalic catecholaminergic neurons, also on the basis of a conditional knock-out of Gdnf gene specifically in parvalbumin-positive neurons of adult mice [25]. In contrast, another study has suggested that GDNF expression was dispensable for the survival of catecholaminergic neurons [82]. It should be noted that none of the conditional Gdnf knock-out studies have achieved complete Gdnf gene ablation. Interestingly, GDNF overexpression from the native locus, i.e., in parvalbumin-positive neurons, leads to an increased number of dopaminergic neurons in the substantia nigra, increased dopamine transporter (DAT) activity, increased dopamine neurotransmission, and improved motor behavior [19].

From a mainly neuron-derived secretion with specific neurotrophic action during development, GDNF becomes a glia-derived factor that can rescue neurons but also possibly support glial cell activation during neuroinflammation $[35,75]$ (See Figure 1).

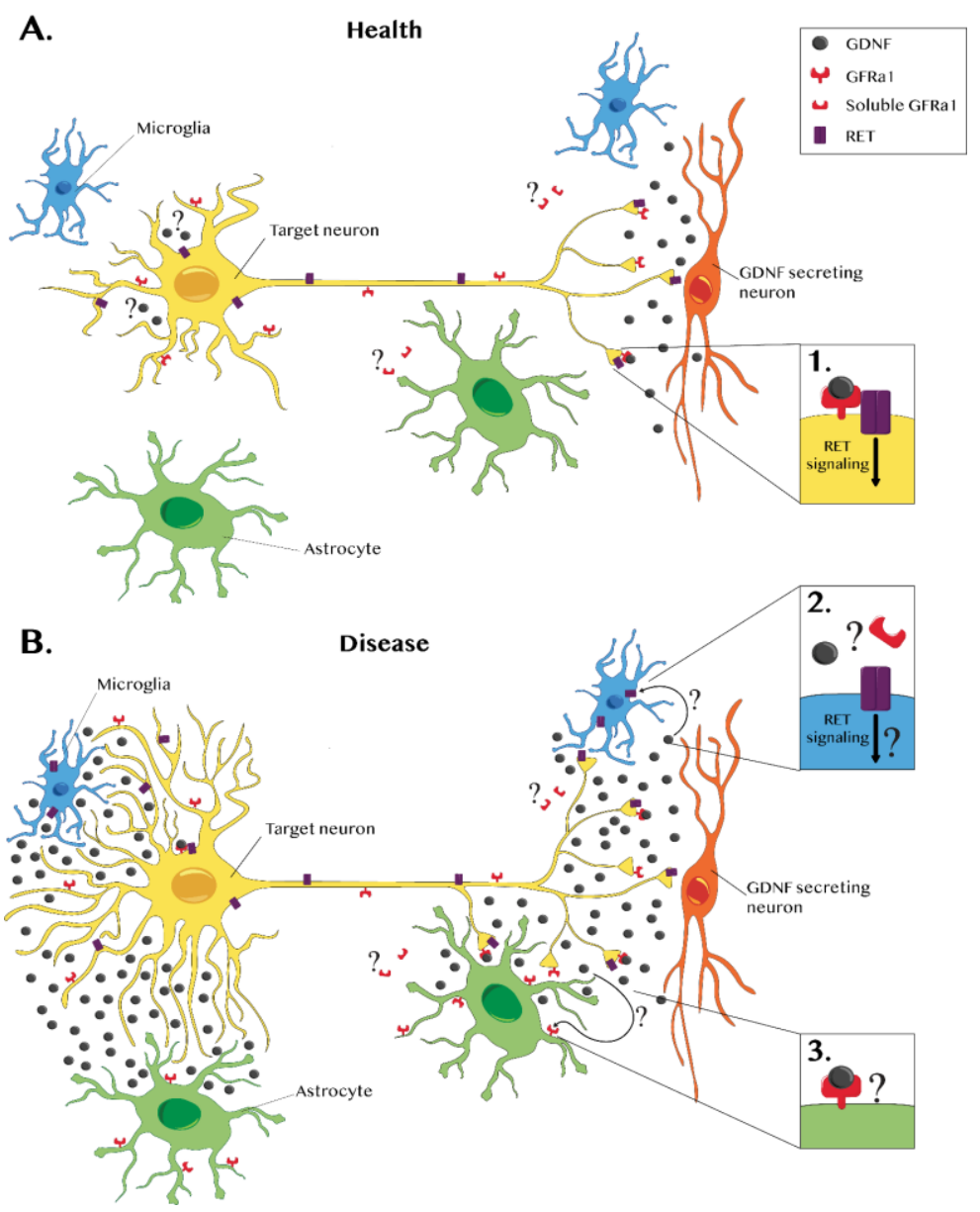

Figure 1. Glial cell line-derived neurotrophic factor (GDNF) and GDNF receptors in a healthy brain and during disease. (A) In a healthy nervous system, GDNF expression is mainly neuronal (red). GDNF forms a complex with the GDNF family receptor alpha 1 (GFR $\alpha 1$ ), which is present in the neuronal membrane. This complex binds to RET, a transmembrane receptor, triggering an intracellular signaling cascade that promotes survival (see inset 1 ). A few in vitro studies have reported that GFR $\alpha 1$ also exists 
in a soluble form, suggesting that GDNF can have broader effects. However, these data lack in vivo confirmation. Some neurons express GDNF and its receptors. Therefore, a possible autocrine GDNF effect should not be excluded even though it has not been demonstrated yet. (B) Several studies report that during disease, glial cells can also express GDNF. Glial GDNF expression can promote survival and axonal growth, but sustained GDNF overexpression or ectopic GDNF expression can lead to aberrant sprouting. In pathological cases, the microglia (blue) express RET but not GFR $\alpha 1$, suggesting that RET signaling may occur in a GDNF-independent manner or through a GFR $\alpha 1$ soluble form (see inset 2). In disease conditions, GFR $\alpha 1$ is upregulated in astrocytes (green), but there is no evidence of RET expression (see inset 3). Further investigation is required to establish the effects of GDNF-GFR $\alpha 1$ astrocytic interactions.

In pathological conditions, astrocytic GDNF expression has been reported and shown to be beneficial $[39,83]$. However, transgenic mice overexpressing GDNF in astrocytes present adverse effects such as TH downregulation, decreased dopamine neurotransmission, and motor deficits [28]. Taken together, these results suggest that prolonged astrocytic overexpression is harmful.

On other hand, microglial GDNF expression has been reported to have beneficial effects in Parkinson's disease and other animal models of inflammation [36,41-43,47,51]. Moreover, after transplantation, genetically-modified hematopoietic stem cells expressing GDNF migrate to the areas affected by dopaminergic neuron loss in the close surroundings of remaining TH positive cells and achieve neuroprotection and motor improvements [52,53]. To our knowledge, adverse effects of microglial GDNF expression have not been reported.

Activated microglia and astrocytes exist in different states, which can be neuroprotective $[41-43,84,85]$ or neurotoxic $[50,86]$. Numerous studies suggest that acute neuroinflammation resulting in the phagocytosis of dead cell debris is beneficial. In contrast, continuous neuroinflammation becomes deleterious due to the high levels of cytokines, reactive oxygen species, and nitrogen species, which are toxic to neurons [87]. The attenuation of a sustained neuroinflammatory response actually increases neuronal survival [75].

Neuroinflammation has been shown to induce the de novo expression of GDNF in glial cells [36, 43,88 ], possibly via the nuclear factor-kappa B (NF- $\mathrm{kB}$ )-responsive elements present in the GDNF promoter [89-91]. In turn, GDNF, after binding to GFR $\alpha 1$ (also upregulated in disease), could possibly increase the survival of the activated microglia through the activation of RET signaling. It is, therefore, tempting to hypothesize that in situations where the neuroinflammatory process becomes uncontrollable, disease-induced GDNF could contribute to perpetuate microglial activation. Astrocytes were shown to express GDNF and GFR $\alpha 1$, but not RET, under pathological conditions [34]. However, since GFR $\alpha 1$ is a diffusible factor, GDNF could induce trophic signaling in other cell types expressing RET or NCAM.

GDNF and neurturin have been proposed to be therapeutic agents for PD [9-11]. Although functional improvements were observed by PET scan imaging [11,12,92], and fiber sprouting was observed in post-mortem samples [13,93], the clinical benefits were very modest.

The emerging picture of the deleterious effects of long-term uncontrolled GDNF overexpression suggests that clinical benefits could have been reduced by aberrant neurotrophic activity inhibiting bona fide neuronal circuit repair.

In gene therapy paradigms using GFL [9,94], our assumption is that transgene expression should be controlled to avoid aberrant sprouting and the perpetuation of neuroinflammatory processes, which can become deleterious. Clinically-acceptable genetic switches are becoming available and could improve the outcomes of future clinical trials using GFL [8,95-101].

Author Contributions: M.D.A. and L.T. conceptualized and wrote the manuscript, all authors edited the text, and S.S. designed and realized the figure. All authors have read and agreed to the published version of the manuscript. 
Funding: This work was supported by a grant from the Swiss National Foundation (SNF grant number 31003A_179527).

Acknowledgments: We thank Cheryl Jeanneret for her careful proofreading of the manuscript.

Conflicts of Interest: The authors declare no conflict of interest.

\section{References}

1. Lin, L.F.; Doherty, D.H.; Lile, J.D.; Bektesh, S.; Collins, F. GDNF: A glial cell line-derived neurotrophic factor for midbrain dopaminergic neurons. Science 1993, 260, 1130-1132. [CrossRef] [PubMed]

2. Kirik, D.; Rosenblad, C.; Bjorklund, A.; Mandel, R.J. Long-term rAAV-mediated gene transfer of GDNF in the rat Parkinson's model: Intrastriatal but not intranigral transduction promotes functional regeneration in the lesioned nigrostriatal system. J. Neurosci. 2000, 20, 4686-4700. [CrossRef] [PubMed]

3. Ramaswamy, S.; McBride, J.L.; Han, I.; Berry-Kravis, E.M.; Zhou, L.; Herzog, C.D.; Gasmi, M.; Bartus, R.T.; Kordower, J.H. Intrastriatal CERE-120 (AAV-Neurturin) protects striatal and cortical neurons and delays motor deficits in a transgenic mouse model of Huntington's disease. Neurobiol. Dis. 2009, 34, 40-50. [CrossRef] [PubMed]

4. Blits, B.; Carlstedt, T.P.; Ruitenberg, M.J.; de Winter, F.; Hermens, W.T.; Dijkhuizen, P.A.; Claasens, J.W.; Eggers, R.; van der Sluis, R.; Tenenbaum, L.; et al. Rescue and sprouting of motoneurons following ventral root avulsion and reimplantation combined with intraspinal adeno-associated viral vector-mediated expression of glial cell line-derived neurotrophic factor or brain-derived neurotrophic factor. Exp. Neurol. 2004, 189, 303-316. [CrossRef] [PubMed]

5. Georgievska, B.; Kirik, D.; Bjorklund, A. Aberrant sprouting and downregulation of tyrosine hydroxylase in lesioned nigrostriatal dopamine neurons induced by long-lasting overexpression of glial cell line derived neurotrophic factor in the striatum by lentiviral gene transfer. Exp. Neurol. 2002, 177, 461-474. [CrossRef] [PubMed]

6. $\quad$ Eggers, R.; Hendriks, W.T.; Tannemaat, M.R.; van Heerikhuize, J.J.; Pool, C.W.; Carlstedt, T.P.; Zaldumbide, A.; Hoeben, R.C.; Boer, G.J.; Verhaagen, J. Neuroregenerative effects of lentiviral vector-mediated GDNF expression in reimplanted ventral roots. Mol. Cell Neurosci. 2008, 39, 105-117. [CrossRef] [PubMed]

7. Tenenbaum, L.; Humbert-Claude, M. Glial Cell Line-Derived Neurotrophic Factor Gene Delivery in Parkinson's Disease: A Delicate Balance between Neuroprotection, Trophic Effects, and Unwanted Compensatory Mechanisms. Front. Neuroanat. 2017, 11, 29. [CrossRef]

8. $\quad$ Eggers, R.; de Winter, F.; Hoyng, S.A.; Hoeben, R.C.; Malessy, M.J.A.; Tannemaat, M.R.; Verhaagen, J. Timed GDNF gene therapy using an immune-evasive gene switch promotes long distance axon regeneration. Brain 2019, 142, 295-311. [CrossRef]

9. Marks, W.J., Jr.; Bartus, R.T.; Siffert, J.; Davis, C.S.; Lozano, A.; Boulis, N.; Vitek, J.; Stacy, M.; Turner, D.; Verhagen, L.; et al. Gene delivery of AAV2-neurturin for Parkinson's disease: A double-blind, randomised, controlled trial. Lancet Neurol. 2010, 9, 1164-1172. [CrossRef]

10. Lang, A.E.; Gill, S.; Patel, N.K.; Lozano, A.; Nutt, J.G.; Penn, R.; Brooks, D.J.; Hotton, G.; Moro, E.; Heywood, P.; et al. Randomized controlled trial of intraputamenal glial cell line-derived neurotrophic factor infusion in Parkinson disease. Ann. Neurol. 2006, 59, 459-466. [CrossRef]

11. Heiss, J.D.; Lungu, C.; Hammoud, D.A.; Herscovitch, P.; Ehrlich, D.J.; Argersinger, D.P.; Sinharay, S.; Scott, G.; $\mathrm{Wu}, \mathrm{T}$; Federoff, H.J.; et al. Trial of magnetic resonance-guided putaminal gene therapy for advanced Parkinson's disease. Mov. Disord. 2019, 34, 1073-1078. [CrossRef] [PubMed]

12. Whone, A.; Luz, M.; Boca, M.; Woolley, M.; Mooney, L.; Dharia, S.; Broadfoot, J.; Cronin, D.; Schroers, C.; Barua, N.U.; et al. Randomized trial of intermittent intraputamenal glial cell line-derived neurotrophic factor in Parkinson's disease. Brain 2019, 142, 512-525. [CrossRef] [PubMed]

13. Bartus, R.T.; Kordower, J.H.; Johnson, E.M., Jr.; Brown, L.; Kruegel, B.R.; Chu, Y.; Baumann, T.L.; Lang, A.E.; Olanow, C.W.; Herzog, C.D. Post-mortem assessment of the short and long-term effects of the trophic factor neurturin in patients with $\alpha$-synucleinopathies. Neurobiol. Dis. 2015, 78, 162-171. [CrossRef] [PubMed]

14. Ernsberger, U. The role of GDNF family ligand signalling in the differentiation of sympathetic and dorsal root ganglion neurons. Cell Tissue Res. 2008, 333, 353-371. [CrossRef] [PubMed]

15. Pozas, E.; Ibanez, C.F. GDNF and GFRalpha1 promote differentiation and tangential migration of cortical GABAergic neurons. Neuron 2005, 45, 701-713. [CrossRef] [PubMed] 
16. Huang, L.; Guo, H.; Hellard, D.T.; Katz, D.M. Glial cell line-derived neurotrophic factor (GDNF) is required for differentiation of pontine noradrenergic neurons and patterning of central respiratory output. Neuroscience 2005, 130, 95-105. [CrossRef]

17. Hellmich, H.L.; Kos, L.; Cho, E.S.; Mahon, K.A.; Zimmer, A. Embryonic expression of glial cell-line derived neurotrophic factor (GDNF) suggests multiple developmental roles in neural differentiation and epithelial-mesenchymal interactions. Mech. Dev. 1996, 54, 95-105. [CrossRef]

18. Hidalgo-Figueroa, M.; Bonilla, S.; Gutierrez, F.; Pascual, A.; Lopez-Barneo, J. GDNF is predominantly expressed in the $\mathrm{PV}+$ neostriatal interneuronal ensemble in normal mouse and after injury of the nigrostriatal pathway. J. Neurosci. 2012, 32, 864-872. [CrossRef]

19. Kumar, A.; Kopra, J.; Varendi, K.; Porokuokka, L.L.; Panhelainen, A.; Kuure, S.; Marshall, P.; Karalija, N.; Harma, M.A.; Vilenius, C.; et al. GDNF Overexpression from the native locus reveals its role in the nigrostriatal dopaminergic system function. PLoS Genet. 2015, 11, e1005710. [CrossRef]

20. Pochon, N.A.; Menoud, A.; Tseng, J.L.; Zurn, A.D.; Aebischer, P. Neuronal GDNF expression in the adult rat nervous system identified by in situ hybridization. Eur. J. Neurosci. 1997, 9, 463-471. [CrossRef]

21. Widenfalk, J.; Nosrat, C.; Tomac, A.; Westphal, H.; Hoffer, B.; Olson, L. Neurturin and glial cell line-derived neurotrophic factor receptor- $\beta$ (GDNFR- $\beta$ ), novel proteins related to GDNF and GDNFR- $\alpha$ with specific cellular patterns of expression suggesting roles in the developing and adult nervous system and in peripheral organs. J. Neurosci. 1997, 17, 8506-8519. [CrossRef] [PubMed]

22. Trupp, M.; Belluardo, N.; Funakoshi, H.; Ibanez, C.F. Complementary and overlapping expression of glial cell line-derived neurotrophic factor (GDNF), c-ret proto-oncogene, and GDNF receptor- $\alpha$ indicates multiple mechanisms of trophic actions in the adult rat CNS. J. Neurosci. 1997, 17, 3554-3567. [CrossRef] [PubMed]

23. Lonka-Nevalaita, L.; Lume, M.; Leppanen, S.; Jokitalo, E.; Peranen, J.; Saarma, M. Characterization of the intracellular localization, processing, and secretion of two glial cell line-derived neurotrophic factor splice isoforms. J. Neurosci. 2010, 30, 11403-11413. [CrossRef] [PubMed]

24. Bizon, J.L.; Lauterborn, J.C.; Gall, C.M. Subpopulations of striatal interneurons can be distinguished on the basis of neurotrophic factor expression. J. Comp. Neurol. 1999, 408, 283-298. [CrossRef]

25. Enterria-Morales, D.; Lopez-Lopez, I.; Lopez-Barneo, J.; d'Anglemont de Tassigny, X. Role of glial cell line-derived neurotrophic factor in the maintenance of adult mesencephalic catecholaminergic neurons. Mov. Disord. 2020. [CrossRef] [PubMed]

26. Poyhonen, S.; Er, S.; Domanskyi, A.; Airavaara, M. Effects of neurotrophic factors in glial cells in the central nervous system: Expression and properties in neurodegeneration and injury. Front. Physiol. 2019, 10, 486. [CrossRef]

27. Saavedra, A.; Baltazar, G.; Duarte, E.P. Driving GDNF expression: The green and the red traffic lights. Prog. Neurobiol. 2008, 86, 186-215. [CrossRef]

28. Sotoyama, H.; Iwakura, Y.; Oda, K.; Sasaoka, T.; Takei, N.; Kakita, A.; Enomoto, H.; Nawa, H. Striatal hypodopamine phenotypes found in transgenic mice that overexpress glial cell line-derived neurotrophic factor. Neurosci. Lett. 2017, 654, 99-106. [CrossRef]

29. Nosrat, C.A.; Tomac, A.; Lindqvist, E.; Lindskog, S.; Humpel, C.; Stromberg, I.; Ebendal, T.; Hoffer, B.J.; Olson, L. Cellular expression of GDNF mRNA suggests multiple functions inside and outside the nervous system. Cell Tissue Res. 1996, 286, 191-207. [CrossRef]

30. Golden, J.P.; DeMaro, J.A.; Osborne, P.A.; Milbrandt, J.; Johnson, E.M., Jr. Expression of neurturin, GDNF, and GDNF family-receptor mRNA in the developing and mature mouse. Exp. Neurol. 1999, 158, 504-528. [CrossRef]

31. Ortega-de San Luis, C.; Pascual, A. Simultaneous detection of both GDNF and GFR $\alpha 1$ expression patterns in the mouse central nervous system. Front. Neuroanat. 2016, 10, 73. [CrossRef]

32. Ubhi, K.; Rockenstein, E.; Mante, M.; Inglis, C.; Adame, A.; Patrick, C.; Whitney, K.; Masliah, E. Neurodegeneration in a transgenic mouse model of multiple system atrophy is associated with altered expression of oligodendroglial-derived neurotrophic factors. J. Neurosci. 2010, 30, 6236-6246. [CrossRef] [PubMed]

33. Merienne, N.; Meunier, C.; Schneider, A.; Seguin, J.; Nair, S.S.; Rocher, A.B.; Le Gras, S.; Keime, C.; Faull, R.; Pellerin, L.; et al. Cell-type-specific gene expression profiling in adult mouse brain reveals normal and disease-state signatures. Cell Rep. 2019, 26, 2477-2493 e2479. [CrossRef] [PubMed] 
34. Marco, S.; Canudas, A.M.; Canals, J.M.; Gavalda, N.; Perez-Navarro, E.; Alberch, J. Excitatory amino acids differentially regulate the expression of GDNF, neurturin, and their receptors in the adult rat striatum. Exp. Neurol. 2002, 174, 243-252. [CrossRef] [PubMed]

35. Bresjanac, M.; Antauer, G. Reactive astrocytes of the quinolinic acid-lesioned rat striatum express GFR $\alpha 1$ as well as GDNF in vivo. Exp. Neurol. 2000, 164, 53-59. [CrossRef]

36. Iravani, M.M.; Sadeghian, M.; Leung, C.C.; Jenner, P.; Rose, S. Lipopolysaccharide-induced nigral inflammation leads to increased IL- $1 \beta$ tissue content and expression of astrocytic glial cell line-derived neurotrophic factor. Neurosci. Lett. 2012, 510, 138-142. [CrossRef]

37. Nakagawa, T.; Schwartz, J.P. Gene expression profiles of reactive astrocytes in dopamine-depleted striatum. Brain Pathol. 2004, 14, 275-280. [CrossRef]

38. Katoh-Semba, R.; Tsuzuki, M.; Miyazaki, N.; Yoshida, A.; Nakajima, H.; Nakagawa, C.; Kitajima, S.; Matsuda, M. Distribution and immunohistochemical localization of GDNF protein in selected neural and non-neural tissues of rats during development and changes in unilateral 6-hydroxydopamine lesions. Neurosci. Res. 2007, 59, 277-287. [CrossRef]

39. Patel, D.; Jana, A.; Roy, A.; Pahan, K. Cinnamon and its metabolite protect the nigrostriatum in a mouse model of Parkinson's disease via astrocytic GDNF. J. Neuroimmune Pharmacol. 2019, 14, 503-518. [CrossRef]

40. Tokumine, J.; Kakinohana, O.; Cizkova, D.; Smith, D.W.; Marsala, M. Changes in spinal GDNF, BDNF, and NT-3 expression after transient spinal cord ischemia in the rat. J. Neurosci. Res. 2003, 74, 552-561. [CrossRef]

41. Batchelor, P.E.; Porritt, M.J.; Martinello, P.; Parish, C.L.; Liberatore, G.T.; Donnan, G.A.; Howells, D.W. Macrophages and microglia produce local trophic gradients that stimulate axonal sprouting toward but not beyond the wound edge. Mol. Cell Neurosci. 2002, 21, 436-453. [CrossRef] [PubMed]

42. Batchelor, P.E.; Liberatore, G.T.; Wong, J.Y.; Porritt, M.J.; Frerichs, F.; Donnan, G.A.; Howells, D.W. Activated macrophages and microglia induce dopaminergic sprouting in the injured striatum and express brain-derived neurotrophic factor and glial cell line-derived neurotrophic factor. J. Neurosci. 1999, 19, 1708-1716. [CrossRef] [PubMed]

43. Hashimoto, M.; Nitta, A.; Fukumitsu, H.; Nomoto, H.; Shen, L.; Furukawa, S. Inflammation-induced GDNF improves locomotor function after spinal cord injury. Neuroreport 2005, 16, 99-102. [CrossRef] [PubMed]

44. Liberatore, G.T.; Wong, J.Y.; Porritt, M.J.; Donnan, G.A.; Howells, D.W. Expression of glial cell line-derived neurotrophic factor (GDNF) mRNA following mechanical injury to mouse striatum. Neuroreport 1997, 8 , 3097-3101. [CrossRef]

45. Ahn, M.; Jin, J.K.; Moon, C.; Matsumoto, Y.; Koh, C.S.; Shin, T. Glial cell line-derived neurotrophic factor is expressed by inflammatory cells in the sciatic nerves of Lewis rats with experimental autoimmune neuritis. J. Peripher. Nerv. Syst. 2010, 15, 104-112. [CrossRef]

46. Chen, L.W.; Zhang, J.P.; Kwok-Yan Shum, D.; Chan, Y.S. Localization of nerve growth factor, neurotrophin-3, and glial cell line-derived neurotrophic factor in nestin-expressing reactive astrocytes in the caudate-putamen of 1-methyl-4-phenyl-1,2,3,6-tetrahydropyridine-treated C57/Bl mice. J. Comp. Neurol. 2006, 497, 898-909. [CrossRef]

47. Kitamura, Y.; Inden, M.; Minamino, H.; Abe, M.; Takata, K.; Taniguchi, T. The 6-hydroxydopamine-induced nigrostriatal neurodegeneration produces microglia-like NG2 glial cells in the rat substantia nigra. Glia 2010, 58, 1686-1700. [CrossRef]

48. Smirkin, A.; Matsumoto, H.; Takahashi, H.; Inoue, A.; Tagawa, M.; Ohue, S.; Watanabe, H.; Yano, H.; Kumon, Y.; Ohnishi, T.; et al. Iba1 ${ }^{+} / \mathrm{NG}^{+}$macrophage-like cells expressing a variety of neuroprotective factors ameliorate ischemic damage of the brain. J. Cereb. Blood Flow Metab. 2010, 30, 603-615. [CrossRef]

49. Sawada, H.; Hishida, R.; Hirata, Y.; Ono, K.; Suzuki, H.; Muramatsu, S.; Nakano, I.; Nagatsu, T.; Sawada, M. Activated microglia affect the nigro-striatal dopamine neurons differently in neonatal and aged mice treated with 1-methyl-4-phenyl-1,2,3,6-tetrahydropyridine. J. Neurosci. Res. 2007, 85, 1752-1761. [CrossRef]

50. Kanthasamy, A.; Jin, H.; Charli, A.; Vellareddy, A.; Kanthasamy, A. Environmental neurotoxicant-induced dopaminergic neurodegeneration: A potential link to impaired neuroinflammatory mechanisms. Pharmacol. Ther. 2019, 197, 61-82. [CrossRef]

51. Batchelor, P.E.; Liberatore, G.T.; Porritt, M.J.; Donnan, G.A.; Howells, D.W. Inhibition of brain-derived neurotrophic factor and glial cell line-derived neurotrophic factor expression reduces dopaminergic sprouting in the injured striatum. Eur. J. Neurosci. 2000, 12, 3462-3468. [CrossRef] [PubMed] 
52. Chen, C.; Guderyon, M.J.; Li, Y.; Ge, G.; Bhattacharjee, A.; Ballard, C.; He, Z.; Masliah, E.; Clark, R.A.; O'Connor, J.C.; et al. Non-toxic HSC transplantation-based macrophage/microglia-mediated GDNF delivery for Parkinson's disease. Mol. Ther. Methods Clin. Dev. 2020, 17, 83-98. [CrossRef] [PubMed]

53. Chen, C.; Li, X.; Ge, G.; Liu, J.; Biju, K.C.; Laing, S.D.; Qian, Y.; Ballard, C.; He, Z.; Masliah, E.; et al. GDNF-expressing macrophages mitigate loss of dopamine neurons and improve Parkinsonian symptoms in MitoPark mice. Sci. Rep. 2018, 8, 5460. [CrossRef] [PubMed]

54. Georgievska, B.; Kirik, D.; Bjorklund, A. Overexpression of glial cell line-derived neurotrophic factor using a lentiviral vector induces time- and dose-dependent downregulation of tyrosine hydroxylase in the intact nigrostriatal dopamine system. J. Neurosci. 2004, 24, 6437-6445. [CrossRef]

55. Paratcha, G.; Ledda, F.; Baars, L.; Coulpier, M.; Besset, V.; Anders, J.; Scott, R.; Ibanez, C.F. Released GFR $\alpha 1$ potentiates downstream signaling, neuronal survival, and differentiation via a novel mechanism of recruitment of c-Ret to lipid rafts. Neuron 2001, 29, 171-184. [CrossRef]

56. Mikaels-Edman, A.; Baudet, C.; Ernfors, P. Soluble and bound forms of GFR $\alpha 1$ elicit different GDNF-independent neurite growth responses in primary sensory neurons. Dev. Dyn. 2003, 227, 27-34. [CrossRef]

57. Airaksinen, M.S.; Titievsky, A.; Saarma, M. GDNF family neurotrophic factor signaling: Four masters, one servant? Mol. Cell Neurosci. 1999, 13, 313-325. [CrossRef]

58. Hoffer, B.J.; Hoffman, A.; Bowenkamp, K.; Huettl, P.; Hudson, J.; Martin, D.; Lin, L.F.; Gerhardt, G.A. Glial cell line-derived neurotrophic factor reverses toxin-induced injury to midbrain dopaminergic neurons in vivo. Neurosci. Lett. 1994, 182, 107-111. [CrossRef]

59. Tomac, A.; Widenfalk, J.; Lin, L.F.; Kohno, T.; Ebendal, T.; Hoffer, B.J.; Olson, L. Retrograde axonal transport of glial cell line-derived neurotrophic factor in the adult nigrostriatal system suggests a trophic role in the adult. Proc. Natl. Acad. Sci. USA 1995, 92, 8274-8278. [CrossRef]

60. Henderson, C.E.; Phillips, H.S.; Pollock, R.A.; Davies, A.M.; Lemeulle, C.; Armanini, M.; Simmons, L.; Moffet, B.; Vandlen, R.A.; Simpson, L.L.C. GDNF: A potent survival factor for motoneurons present in peripheral nerve and muscle. Science 1994, 266, 1062-1064. [CrossRef]

61. Arenas, E.; Trupp, M.; Akerud, P.; Ibanez, C.F. GDNF prevents degeneration and promotes the phenotype of brain noradrenergic neurons in vivo. Neuron 1995, 15, 1465-1473. [CrossRef]

62. Rodrigues, D.M.; Li, A.Y.; Nair, D.G.; Blennerhassett, M.G. Glial cell line-derived neurotrophic factor is a key neurotrophin in the postnatal enteric nervous system. Neurogastroenterol. Motil. 2011, 23, e44-e56. [CrossRef] [PubMed]

63. Liu, Y.; Okada, T.; Shimazaki, K.; Sheykholeslami, K.; Nomoto, T.; Muramatsu, S.I.; Mizukami, H.; Kume, A.; Xiao, S.; Ichimura, K.; et al. Protection against aminoglycoside-induced ototoxicity by regulated AAV vector-mediated GDNF gene transfer into the cochlea. Mol. Ther. 2008, 16, 474-480. [CrossRef]

64. Cao, J.P.; Wang, H.J.; Yu, J.K.; Yang, H.; Xiao, C.H.; Gao, D.S. Involvement of NCAM in the effects of GDNF on the neurite outgrowth in the dopamine neurons. Neurosci. Res. 2008, 61, 390-397. [CrossRef]

65. Paratcha, G.; Ledda, F.; Ibanez, C.F. The neural cell adhesion molecule NCAM is an alternative signaling receptor for GDNF family ligands. Cell 2003, 113, 867-879. [CrossRef]

66. Ledda, F.; Paratcha, G.; Sandoval-Guzman, T.; Ibanez, C.F. GDNF and GFRalpha1 promote formation of neuronal synapses by ligand-induced cell adhesion. Nat. Neurosci. 2007, 10, 293-300. [CrossRef] [PubMed]

67. Sergaki, M.C.; Ibanez, C.F. GFR $\alpha 1$ regulates purkinje cell migration by counteracting NCAM function. Cell Rep. 2017, 18, 367-379. [CrossRef]

68. Chen, J.; Kawamura, T.; Sethi, M.K.; Zaia, J.; Repunte-Canonigo, V.; Sanna, P.P. Heparan sulfate: Resilience factor and therapeutic target for cocaine abuse. Sci. Rep. 2017, 7, 13931. [CrossRef]

69. Bespalov, M.M.; Sidorova, Y.A.; Tumova, S.; Ahonen-Bishopp, A.; Magalhaes, A.C.; Kulesskiy, E.; Paveliev, M.; Rivera, C.; Rauvala, H.; Saarma, M. Heparan sulfate proteoglycan syndecan-3 is a novel receptor for GDNF, neurturin, and artemin. J. Cell Biol. 2011, 192, 153-169. [CrossRef]

70. Sariola, H.; Saarma, M. Novel functions and signalling pathways for GDNF. J. Cell Sci. 2003, 116, 3855-3862. [CrossRef]

71. Piltonen, M.; Bespalov, M.M.; Ervasti, D.; Matilainen, T.; Sidorova, Y.A.; Rauvala, H.; Saarma, M.; Mannisto, P.T. Heparin-binding determinants of GDNF reduce its tissue distribution but are beneficial for the protection of nigral dopaminergic neurons. Exp. Neurol. 2009, 219, 499-506. [CrossRef] [PubMed] 
72. Walker, D.G.; Beach, T.G.; Xu, R.; Lile, J.; Beck, K.D.; McGeer, E.G.; McGeer, P.L. Expression of the proto-oncogene Ret, a component of the GDNF receptor complex, persists in human substantia nigra neurons in Parkinson's disease. Brain Res. 1998, 792, 207-217. [CrossRef]

73. Boscia, F.; Esposito, C.L.; Di Crisci, A.; de Franciscis, V.; Annunziato, L.; Cerchia, L. GDNF selectively induces microglial activation and neuronal survival in CA1/CA3 hippocampal regions exposed to NMDA insult through Ret/ERK signalling. PLoS ONE 2009, 4, e6486. [CrossRef] [PubMed]

74. Ryu, H.; Jeon, G.S.; Cashman, N.R.; Kowall, N.W.; Lee, J. Differential expression of c-Ret in motor neurons versus non-neuronal cells is linked to the pathogenesis of ALS. Lab. Invest. 2011, 91, 342-352. [CrossRef]

75. Lee, J.; Hyeon, S.J.; Im, H.; Ryu, H.; Kim, Y.; Ryu, H. Astrocytes and microglia as non-cell autonomous players in the pathogenesis of ALS. Exp. Neurobiol. 2016, 25, 233-240. [CrossRef]

76. Widenfalk, J.; Lundstromer, K.; Jubran, M.; Brene, S.; Olson, L. Neurotrophic factors and receptors in the immature and adult spinal cord after mechanical injury or kainic acid. J. Neurosci. 2001, 21, 3457-3475. [CrossRef]

77. Defaux, A.; Zurich, M.G.; Honegger, P.; Monnet-Tschudi, F. Inflammatory responses in aggregating rat brain cell cultures subjected to different demyelinating conditions. Brain Res. 2010, 1353, 213-224. [CrossRef]

78. Boscia, F.; Esposito, C.L.; Casamassa, A.; de Franciscis, V.; Annunziato, L.; Cerchia, L. The isolectin IB4 binds RET receptor tyrosine kinase in microglia. J. Neurochem. 2013, 126, 428-436. [CrossRef]

79. Moore, M.W.; Klein, R.D.; Farinas, I.; Sauer, H.; Armanini, M.; Phillips, H.; Reichardt, L.F.; Ryan, A.M.; Carver-Moore, K.; Rosenthal, A. Renal and neuronal abnormalities in mice lacking GDNF. Nature 1996, 382, 76-79. [CrossRef]

80. Sanchez, M.P.; Silos-Santiago, I.; Frisen, J.; He, B.; Lira, S.A.; Barbacid, M. Renal agenesis and the absence of enteric neurons in mice lacking GDNF. Nature 1996, 382, 70-73. [CrossRef]

81. Pascual, A.; Hidalgo-Figueroa, M.; Piruat, J.I.; Pintado, C.O.; Gomez-Diaz, R.; Lopez-Barneo, J. Absolute requirement of GDNF for adult catecholaminergic neuron survival. Nat. Neurosci. 2008, 11, 755-761. [CrossRef] [PubMed]

82. Kopra, J.; Vilenius, C.; Grealish, S.; Harma, M.A.; Varendi, K.; Lindholm, J.; Castren, E.; Voikar, V.; Bjorklund, A.; Piepponen, T.P.; et al. GDNF is not required for catecholaminergic neuron survival in vivo. Nat. Neurosci. 2015, 18, 319-322. [CrossRef] [PubMed]

83. Drinkut, A.; Tereshchenko, Y.; Schulz, J.B.; Bahr, M.; Kugler, S. Efficient gene therapy for Parkinson's disease using astrocytes as hosts for localized neurotrophic factor delivery. Mol. Ther. 2012, 20, 534-543. [CrossRef] [PubMed]

84. Brown, G.C.; Neher, J.J. Microglial phagocytosis of live neurons. Nat. Rev. Neurosci. 2014, 15, $209-216$. [CrossRef]

85. Sawada, H.; Suzuki, H.; Nagatsu, T.; Sawada, M. Neuroprotective and neurotoxic phenotypes of activated microglia in neonatal mice with respective MPTP- and ethanol-induced brain injury. Neurodegener. Dis. 2010, 7, 64-67. [CrossRef]

86. London, A.; Cohen, M.; Schwartz, M. Microglia and monocyte-derived macrophages: Functionally distinct populations that act in concert in CNS plasticity and repair. Front. Cell Neurosci. 2013, 7, 34. [CrossRef]

87. Mansour, R.M.; Ahmed, M.A.E.; El-Sahar, A.E.; El Sayed, N.S. Montelukast attenuates rotenone-induced microglial activation/p38 MAPK expression in rats: Possible role of its antioxidant, anti-inflammatory and antiapoptotic effects. Toxicol. Appl. Pharmacol. 2018, 358, 76-85. [CrossRef]

88. Bian, Y.; Zhao, X.; Li, M.; Zeng, S.; Zhao, B. Various roles of astrocytes during recovery from repeated exposure to different doses of lipopolysaccharide. Behav. Brain Res. 2013, 253, 253-261. [CrossRef]

89. Woodbury, D.; Schaar, D.G.; Ramakrishnan, L.; Black, I.B. Novel structure of the human GDNF gene. Brain Res. 1998, 803, 95-104. [CrossRef]

90. Tanaka, M.; Ito, S.; Matsushita, N.; Mori, N.; Kiuchi, K. Promoter analysis and characteristics of the $5^{\prime}$-untranslated region of the mouse glial cell line-derived neurotrophic factor gene. Brain Res. Mol. Brain Res. 2000, 85, 91-102. [CrossRef]

91. Baecker, P.A.; Lee, W.H.; Verity, A.N.; Eglen, R.M.; Johnson, R.M. Characterization of a promoter for the human glial cell line-derived neurotrophic factor gene. Brain Res. Mol. Brain Res. 1999, 69, $209-222$. [CrossRef] 
92. Whone, A.L.; Boca, M.; Luz, M.; Woolley, M.; Mooney, L.; Dharia, S.; Broadfoot, J.; Cronin, D.; Schroers, C.; Barua, N.U.; et al. Extended treatment with glial cell line-derived neurotrophic factor in Parkinson's disease. J. Parkinsons Dis. 2019, 9, 301-313. [CrossRef] [PubMed]

93. Bartus, R.T.; Herzog, C.D.; Chu, Y.; Wilson, A.; Brown, L.; Siffert, J.; Johnson, E.M., Jr.; Olanow, C.W.; Mufson, E.J.; Kordower, J.H. Bioactivity of AAV2-neurturin gene therapy (CERE-120): Differences between Parkinson's disease and nonhuman primate brains. Mov. Disord. 2011, 26, 27-36. [CrossRef] [PubMed]

94. Su, X.; Kells, A.P.; Huang, E.J.; Lee, H.S.; Hadaczek, P.; Beyer, J.; Bringas, J.; Pivirotto, P.; Penticuff, J.; Eberling, J.; et al. Safety evaluation of AAV2-GDNF gene transfer into the dopaminergic nigrostriatal pathway in aged and parkinsonian rhesus monkeys. Hum. Gene Ther. 2009, 20, 1627-1640. [CrossRef] [PubMed]

95. Tereshchenko, J.; Maddalena, A.; Bahr, M.; Kugler, S. Pharmacologically controlled, discontinuous GDNF gene therapy restores motor function in a rat model of Parkinson's disease. Neurobiol. Dis. 2014, 65, 35-42. [CrossRef]

96. Cheng, S.; Tereshchenko, J.; Zimmer, V.; Vachey, G.; Pythoud, C.; Rey, M.; Liefhebber, J.; Raina, A.; Streit, F.; Mazur, A.; et al. Therapeutic efficacy of regulable GDNF expression for Huntington's and Parkinson's disease by a high-induction, background-free “GeneSwitch" vector. Exp. Neurol. 2018, 309, 79-90. [CrossRef] [PubMed]

97. Quintino, L.; Namislo, A.; Davidsson, M.; Breger, L.S.; Kavanagh, P.; Avallone, M.; Elgstrand-Wettergren, E.; Isaksson, C.; Lundberg, C. Destabilizing domains enable long-term and inert regulation of GDNF expression in the brain. Mol. Ther. Methods Clin. Dev. 2018, 11, 29-39. [CrossRef]

98. Chtarto, A.; Humbert-Claude, M.; Bockstael, O.; Das, A.T.; Boutry, S.; Breger, L.S.; Klaver, B.; Melas, C.; Barroso-Chinea, P.; Gonzalez-Hernandez, T.; et al. A regulatable AAV vector mediating GDNF biological effects at clinically-approved sub-antimicrobial doxycycline doses. Mol. Ther. Methods Clin. Dev. 2016, 5, 16027. [CrossRef]

99. Quintino, L.; Manfre, G.; Wettergren, E.E.; Namislo, A.; Isaksson, C.; Lundberg, C. Functional neuroprotection and efficient regulation of GDNF using destabilizing domains in a rodent model of Parkinson's disease. Mol. Ther. 2013, 21, 2169-2180. [CrossRef]

100. Hoyng, S.A.; Gnavi, S.; de Winter, F.; Eggers, R.; Ozawa, T.; Zaldumbide, A.; Hoeben, R.C.; Malessy, M.J.; Verhaagen, J. Developing a potentially immunologically inert tetracycline-regulatable viral vector for gene therapy in the peripheral nerve. Gene Ther. 2014, 21, 549-557. [CrossRef]

101. Eggers, R.; de Winter, F.; Arkenaar, C.; Tannemaat, M.R.; Verhaagen, J. Enhanced regeneration and reinnervation following timed GDNF gene therapy in a cervical ventral root avulsion. Exp. Neurol. 2019, 321, 113037. [CrossRef] [PubMed]

(C) 2020 by the authors. Licensee MDPI, Basel, Switzerland. This article is an open access article distributed under the terms and conditions of the Creative Commons Attribution (CC BY) license (http://creativecommons.org/licenses/by/4.0/). 